\title{
DESIGN, CONSTRUCTION AND PERFORMANCE COMPARISON OF TWO SOLAR STILLS HAVING DIFFERENT ABSORBER DESIGN
}

\author{
A. A. Ibrahim 1 , M. Dauda ${ }^{2}$, G. Y. Pam ${ }^{3}$ and D. 0. Obada, ${ }^{4}$

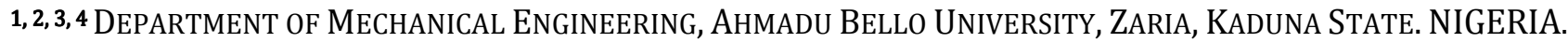 \\ E-mailaddresses:1 danjinjiri8o@yahoo.com,2muhammaddauda@yahoo.com,3gypam@abu.edu.ng, \\ 4 obadavid4@gmail.com
}

\begin{abstract}
Productivity enhancement of solar stills has been one of the main goals of researchers. In this study, two designs of solar stills absorber plate were conceptualized and developed and their effects on the productivity process were investigated experimentally. A solar still using a submerged flat absorber plate and another solar still without any submerged absorber plate were designed and constructed. The designs were developed by virtue of the comparative analyses to be carried out. The two still designs were tested under the same conditions. Comparatively, more distilled water was obtained from the solar still without submerged plate at 10litres of inlet raw water during the first day of experiment while the still with submerged flat absorber had more distillate during the second and third day of the experiment with 20 and 30 liters inlet raw water respectively. The efficiencies were $82.35 \%$ and $83.30 \%$ on the first day of experiment, $82.99 \%$ and $82.56 \%$ on the second day of experiment and 83.82\% and $81.98 \%$ on the third day of experiment for still with submerged flat plate absorber and still without submerged flat plate absorber respectively.
\end{abstract}

Keywords: Solar still, Solar Energy, Fresh Water, Submerged Absorber.

\section{INTRODUCTION}

Without the radiant energy from the Sun in the forms of heat and light (two forms of electromagnetic radiations), life processes on earth will be impossible. However, the efficiency of natural conversion of solar energy is so low (about $1 \%$ ) with attendant wastages that the use of man-made equipment for its collection and utilization becomes inevitable. Solar energy collectors in current use can be broadly classified into concentrating collectors, which employ reflecting mirrors (e.g. parabolic and spherical dishes) and refracting lens in solar energy collection and, non concentrating collectors like the flat plate collector [1] Solar still is a cheap and simple device to get pure water with the use of solar thermal energy. It can be fabricated from locally available materials by even unskilled persons. It is therefore very suitable for the undeveloped and remote regions of the world where electric power is not available or scarce and even in the developed areas, where people have abundantly available sunlight and sufficient space to install the solar distillation units. Solar still is also widely used in solar desalination. Compared with other conventional desalination methods, the yield of the single basin solar still is very low. In order to enhance the performance of conventional solar stills, several designs such as double-basin type [2], multi-basin type [3], wick-basin type [4] and multi wick single slope solar still type [5] have been developed in recent years. Integration of solar still into a multi-source and multi-use environmental type has been also studied [6]. Effect of several parameters on the annual performance of an active solar still has been investigated [7]. Moreover, the effects of the heat exchanger length, mass flow rate of fluid in the heat exchanger loop and water depth in the basin on the performance of an active solar still have been investigated [8]. Influence of using black rubber and black gravel for augmenting productivity of the solar still has been performed [9-11]. Tanaka and Nakatake [10], presented a theoretical analysis of a basin type still with internal and external reflectors. In addition, they discussed the various factors [12] that affect the productivity of a multiple-effect diffusion-type solar 
still coupled with a flat plate reflector. They found that the increase in the daily amounts of distillate for the entire year by adding both the internal and external reflector was averaged as $48 \%$ and that by adding the internal reflector only it was averaged as $22 \%$.

Consequently, one of the current objectives among researchers is the improvement of the overall efficiency of the system [13]. In this case, it is important that the solar system be designed in such a way to improve its efficiency.

The objective of this paper was to compare the efficiencies of a submerged flat absorber plate and a simple conventional solar still. The performances of the systems were compared and results for the modified solar still and the control were discussed.

\subsection{MATERIALS AND METHODS}

\subsection{Design of Solar Distillation Plant}

\subsubsection{Design Considerations}

The performance of any solar thermal energy conversion device is governed by the rates of heat transfer interactions between its component parts and its surroundings [13]. Minimisation of heat loss and maximisation of solar radiation collection will be the major concern. Other considerations were:

i. The stills were designed using average long-term data obtained from the month of minimum insolation which is August.

ii. The stills were designed to produce 1 litre of distilled water per day.

iii. The collector was positioned at an angle of inclination for best year round performance $\left(11^{0} 20^{\prime}\right)$, which is the latitude of Zaria $\left(11^{0}, 20^{1}\right)$

\subsection{Material Selection}

\subsubsection{Still Basin and Submerged Plates}

It is necessary that the material for both the basin and the submerged absorber plate have high absorptivity or very less reflectivity and transmissivity. In this work a blackened aluminium sheet (Thermal conductivity $=205 \mathrm{~W} / \mathrm{m}^{\circ} \mathrm{C}$ ) was used.

\subsubsection{Side Walls}

The walls must be made from materials having low value of thermal conductivity and should be rigid enough to sustain its own weight and the weight of the top cover. For better insulation, a composite wall of saw dust (inside) and wood (outside) was used. The properties of the materials are: Wood (thermal conductivity, $\mathrm{k}_{\mathrm{w}}=0.147 \mathrm{~W} / \mathrm{m}^{0} \mathrm{C}$ ) and saw dust (thermal conductivity, $\mathrm{k}_{\mathrm{th}}=0.08 \mathrm{~W} / \mathrm{m}^{0} \mathrm{C}$ ).

\subsection{Construction of Solar Still \\ 2.3.1 Top Cover}

The top cover was constructed using transparent glass material. The construction was based on the area obtained from design calculation, which is $0.36 \mathrm{~m}^{2}$.

\subsubsection{Still Basin}

The basin was constructed using aluminium sheet. The construction was based on the dimensions arrived at in design calculation, i.e.

Front height is $158 \mathrm{~mm}$. Back height is $246.43 \mathrm{~mm}$, Length is $800 \mathrm{~mm}$, Breadth is $441.23 \mathrm{~mm}$ and Slope length is $450 \mathrm{~mm}$

\subsubsection{Submerged Absorber Plates}

The length of the submerged absorber plates was a little bit less than the length of the still basin so that it could easily fit into the basin. Aluminium sheet was used in the construction, based on the dimensions arrived at in the design calculation.

Submerged Flat Absorber Plate, Length $=700 \mathrm{~mm}$, Breadth $=441.23 \mathrm{~mm}$

\subsubsection{Channel}

The channel started from one side of the basin and then protrudes outwardly from the other side of the basin. Aluminium sheet were used for the construction.

\subsubsection{Thickness of Composite Walls}

The composite walls consist of wood (13mm thick) and saw dust ( $30 \mathrm{~mm}$ thick).

\subsection{Testing of the Solar Still}

In the test, solar intensity, ambient temperature, wind speed, water temperature, inner glass temperature and quantity of water distilled at hourly intervals were measured for analyses of the performance of the still.

The systems were operated simultaneously under the same conditions in order to compare their performances. Experiments were carried out in Mechanical Engineering workshop, ABU Zaria for three days i.e. $6^{\text {th }}, 7^{\text {th }}$ and $8^{\text {th }}$ of February, 2014, to know the performance of the stills by determining the following:

(i) Solar radiation incident on and absorbed by the stills,

(ii) The distillate production and

(iii) Efficiency and capacity of the stills. 


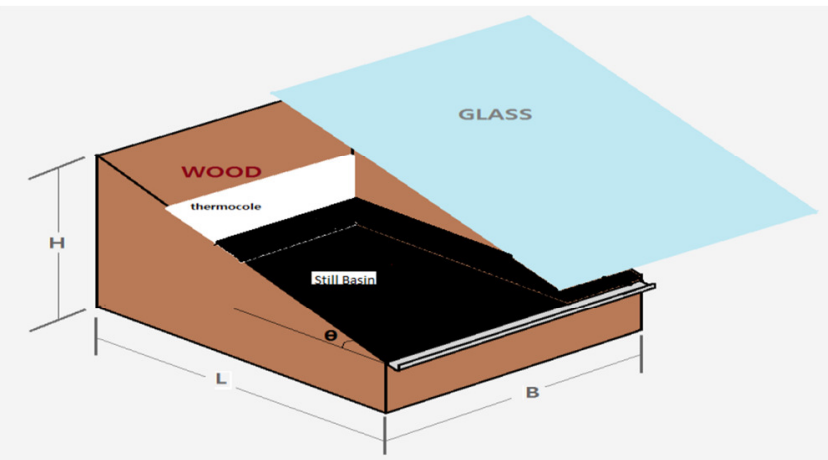

Figure 1: A sketch of the solar stills.

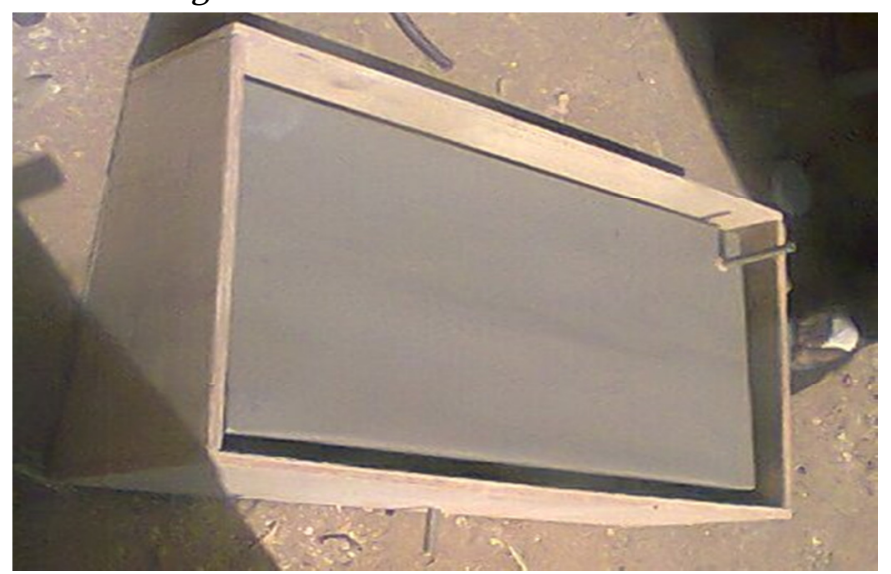

Figure 3: Side walls

The two stills i.e., still with submerged flat absorber plate and still without submerged plate were fed with raw water in the early hours of the day and mounted as shown in Figure 2.

The hourly readings of inside cover temperature, raw water temperature and basin temperature, were measured with the use of copper-constantan thermocouple. Hourly average wind speed, insolation $\left(\mathrm{H}_{\mathrm{s}}\right)$, and quantity of distilled water were also measured using anemometer, calorimeter and calibrated cylinder respectively.

\section{RESULTS AND DISCUSSION}

\subsection{Readings Taken from Stills}

Readings of water temperature $\left(\mathrm{T}_{\mathrm{w}}\right)$, inner glass temperature $\left(\mathrm{T}_{\mathrm{g}}\right)$, distillate quantity (Qty), solar radiation $\left(\mathrm{H}_{\mathrm{s}}\right)$ and wind speed $(\mathrm{v})$ where taken on the first, second, and third days of the experiment. The plots are as shown in the charts as obtained from results in the list of appendices.

As it can be seen from Figures 5, 6 and 7, the temperature variations start from low temperature levels, and at around midday increases and further declines after a few hours. This is as a result of increase in solar energy as the sun approaches the meridian which causes an increase in the absorber

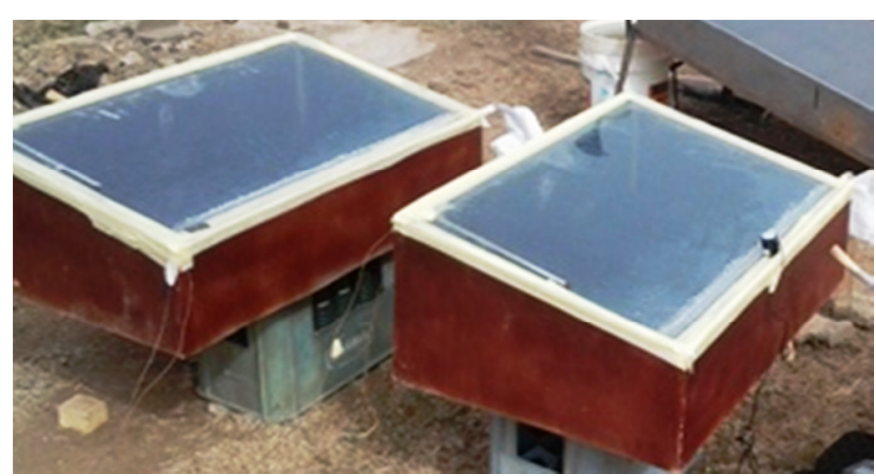

Figure.2: Constructed solar stills

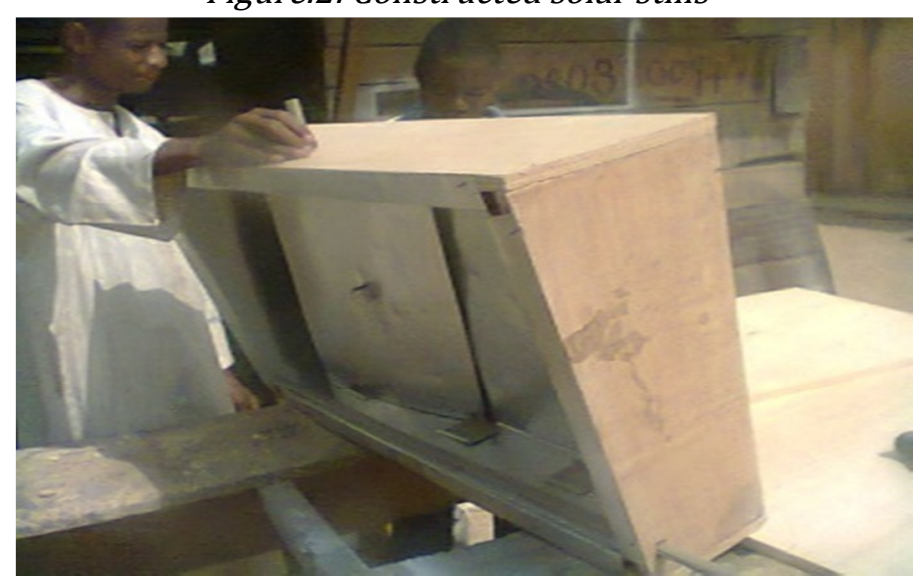

Figure 4: Submerged plates

plate and glass cover temperature. By passing the midday, the trend will be that both temperatures decrease as a result of decrease in the solar radiation energy. As shown in Figures 5, 6 and 7, the absorber plate has a higher temperature in the afternoon compared with the early hours of the day. This is due to the fact that the absorber plate is placed in a closed environment and has no contact with the outside environment. Therefore, the heat dissipation of the absorber is lower and consequently its temperature in the afternoon decreases with lower speed. This results in more vapor production as compared with the early hours of the day. Since the resulting vapors are condensed on the internal surface of the glass cover, the temperature of the glass cover in the afternoon is higher than that of the early hours of the day.

The developed solar stills were evaluated for winter month (February) with load test at $11^{\circ} 20^{1}$ angle. From Figure 8, for the first day of the experiment, it can be seen that the submerged flat plate design had the highest temperature difference and the lowest distillate,

This is because for vaporization to occur which will result in distillate production, energy is needed, the more the amount of energy available in the system, the more distillate that will be produced. 


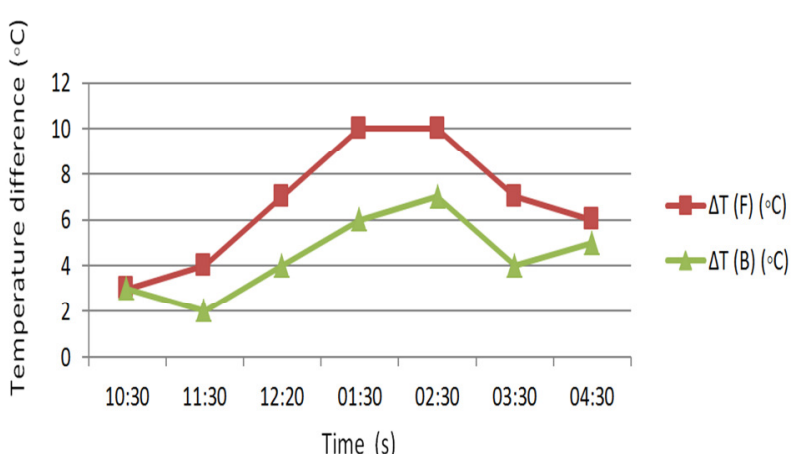

Figure 5: Temperature difference between water and glass against time for day 1

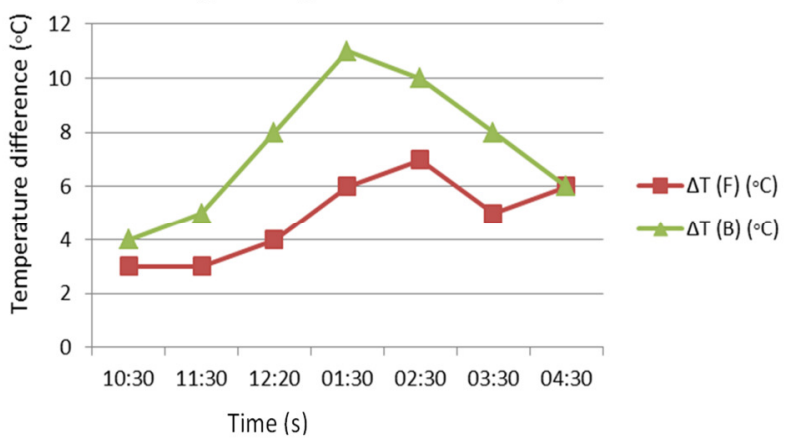

Figure 7: Temperature difference between water and glass against dime for day 3

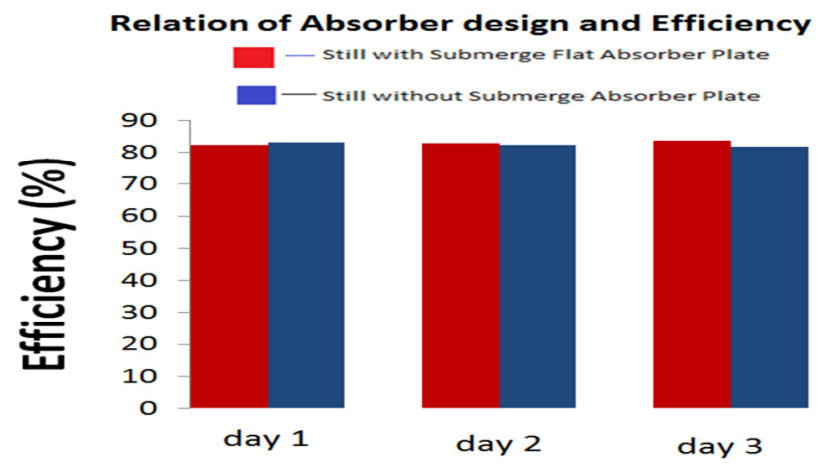

Figure 9: Efficiencies of the two stills

The higher the temperature difference between water and glass, the more the convective heat loss from the still given the same materials of construction (especially insulation) and the location of operation [14]. On the second and third day of the experiment, the still without submerged absorber had higher convective heat loss which led to lower distillate formation.

The submerged flat plate still performed better than the still design without submerge plate in the second and third day of the experiment because the quantity of raw water was increased from $10 \mathrm{~L}$ to $20 \mathrm{~L}$ and $30 \mathrm{~L}$ respectively.

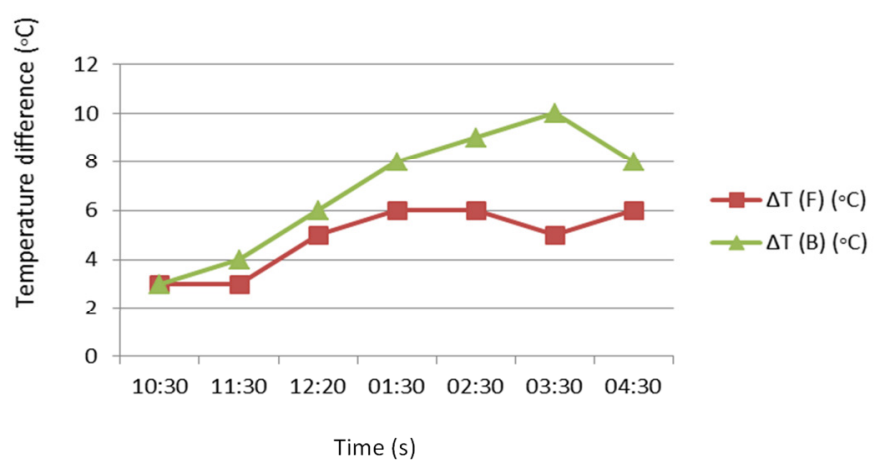

Figure 6: Temperature difference between water and glass against time for day 2

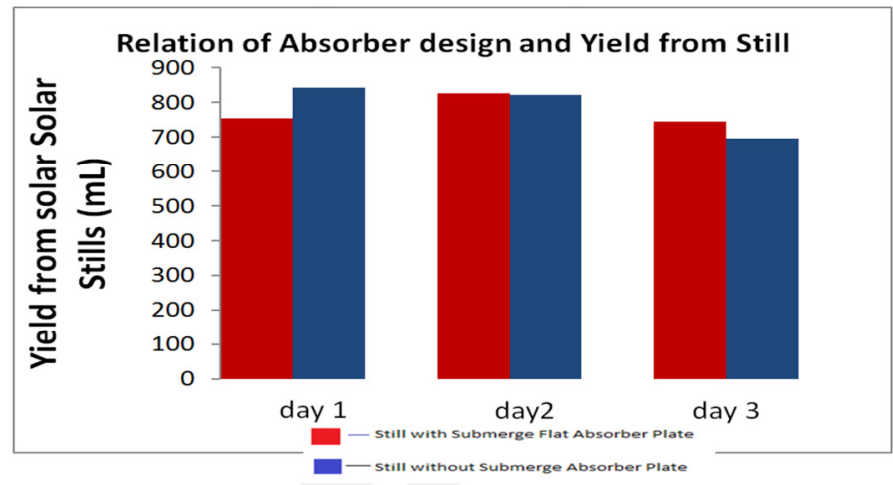

Figure 8: Daily distillate of the two still

\subsection{Calculation of Efficiency and Capacity of the Stills}

Figure 9 shows the results of the calculation done for the efficiency and capacity of the still. The formula used for the calculation can be seen in the Appendices. The efficiency of solar still is a function of how well the incoming solar energy is used to produce distilled water. From Figure 9 which shows the efficiency of the two solar still designs for first, second and third day of the experiment. It can be observed that the efficiency of the still without submerged plate was higher on the first day. This is because it had the lowest heat lost as compared with the other still. While on the second and third days of the experiment as can be seen from Figure 9, the still with submerged flat absorber had higher efficiency, because there were enough raw water above the submerged flat plate to absorb incoming radiation before getting to the absorber, thereby reducing the temperature difference and hence reducing the heat loss by convection.

The introduced modification (submerged flat plate) was found to increase the productivity of the still on the $2^{\text {nd }}$ and $3^{\text {rd }}$ days of experimentation, while maintaining its basic features and advantages such as compactness, sustainability and ease of handling. 


\section{CONCLUSION}

From the results obtained experimentally, appropriate materials were chosen for various components of the still and the design analyses was carried out to obtain the dimensions of the still. At low quantity of raw water (less than 10 litres), the solar still design without submerged absorber plate had the highest quantity of distillate. For higher raw water content, the submerged flat absorber solar still showed huge potentials. Finally, it could be noted that one of the major reasons for efficiency loss in solar stills is incomplete sealing. Hence, proper sealing, which will not be costly and difficult, must be one of the major concerns of solar still designers.

\section{REFERENCES:}

[1] Onuoha. D.V.C., Dynamic Modeling of Natural Convection Solar Energy Collectors for Agricultural Driers I: Theory and Complete Run of the Solutions to the Dynamic Model Equations of SSSCA Flat Plate Collector. Nigerian Journal of Technology, Vol. 26, No. 2, 2007, pp. 82-98.

[2] Al-Karaghouli, A.A., Alnaser, W.E. "Experimental comparative study of the performances of single and double basin solar-stills" .Appl EnergyVol.77,Number 3, 2004, pp317-325.

[3] El-Sebaii,A.. "Thermal performance of a triple-basin solar still”, Desalination, Vol174, Number 1, 2005, pp23-37.

[4] Minasian, AN., Al-Karaghouli, AA. "An improved solar still: The wick-basin type". Energy Conversion and ManagementVol36, Number 3, 1995, pp213-217.

[5] Shukla, S.K, Sorayan, V.P.S. "Thermal modeling of solar stills: an experimental validation". Renewable EnergyVol30, Number 4, 2005, pp 683-699.

[6] Mathioulakis, E., Belessiotis, V.“Integration of solar still in a multi-source, multi-use environment".
Journal of solar energy, Vol75,2003, Number 3,pp 403-411.

[7] Lee D.W and Sharma A. ."Thermal performances of the active and passive water heating systems based on annual operation", Solar Energy, Vol. 81, 2007, pp. 207-215.

[8] Tiwari, G.N, Dhiman, N.K. "Performance study of a high temperature distillation system". Energy Conversion and Management Vol. 32, Number 3, 1991, pp 283-291.

[9] Nafey, A.S., Abdelkade, M., Abdelmotalip, A., Mabrouk, A.A. "Solar still productivity enhancement. Energy Conversion and Management Vol. 42, Number 11, 2001, pp1401-1408.

[10] Nafey, AS., Abdelkader, M., Abdelmotalip, A., Mabrouk, AA. "Enhancement of solar still productivity using floating perforated black plate" Energy Conversion and Management, Vol. 43, Number 12, 2002, pp 937-946.

[11] Tanaka, H, Nakatake Y. "Factors influencing the productivity of a multiple-effect diffusion-type solar still coupled with a flat plate reflector". Desalination, Vol. 186, Number 1, 2005, pp299-310.

[12] Tanaka, H, Nakatake Y. Theoretical analysis of a basin type solar still with internal and external reflectors. Desalination, Vol 197, Number 2, 2006, pp 205-216.

[13] Iloeje 0. C. "Improvement to the Design of a Solid Absorption Solar Refrigerator". Nigerian Journal of Technology, Vol. 12, No. 1, 1988, pp 8-18.

[14] Dasin, D.Y., Asere, A.A. and Habou, D. "Parabolic Solar Cooker Dish: Design and Simulation" Nigerian Journal of Solar Energy, Vol. 22, 2011, pp52-61.

[15] Sahooa B.B, Sahoob N, Mahantab P, Borboraa L, Kalitaa P., Sahab U.K, "Performance assessment of a solar still using blackened surface and thermocol insulation", Renewable Energy, Vol33, 2008, pp1703-1708

\section{APPENDICES.}

Appendix A: Readings from Submerged Flat Absorber Still on 06/03/2014

\begin{tabular}{|c|c|c|c|c|c|c|}
\hline Time & $\mathrm{T}_{\mathrm{w}}\left({ }^{0} \mathrm{C}\right)$ & $\mathrm{T}_{\mathrm{g}}\left({ }^{0} \mathrm{C}\right)$ & $\Delta \mathrm{T}(\mathrm{Tw}-\mathrm{Tg})\left({ }^{\circ} \mathrm{C}\right)$ & Qty (mL) & $\mathrm{H}_{\mathrm{s}}\left(\mathrm{W} / \mathrm{m}^{2}\right)$ & $\mathrm{v}(\mathrm{m} / \mathrm{s})$ \\
\hline $10: 30$ & 35 & 32 & 3 & 0 & 630 & 1.7 \\
\hline $11: 30$ & 37 & 33 & 4 & 15 & 779 & 1.1 \\
\hline $12: 30$ & 42 & 35 & 7 & 78 & 966 & 0.6 \\
\hline $1: 30$ & 49 & 39 & 10 & 161 & 986 & 1.8 \\
\hline $2: 30$ & 51 & 41 & 10 & 280 & 956 & 0.2 \\
\hline $3: 30$ & 45 & 38 & 7 & 330 & 760 & 0.9 \\
\hline $4: 30$ & 40 & 34 & 6 & 413 & 455 & 0.1 \\
\hline $10: 30$ & & & & 340 & & \\
\hline Average & 42.71 & 36 & & & 760.29 & 0.92 \\
\hline Total Distillate & & & & 753 & & \\
\hline
\end{tabular}


Appendix B: Readings from still without Submerged Absorber on 06/03/2014

\begin{tabular}{|c|c|c|c|c|c|c|}
\hline Time & $\mathrm{T}_{\mathrm{w}}\left({ }^{0} \mathrm{C}\right)$ & $\mathrm{T}_{\mathrm{g}}\left({ }^{0} \mathrm{C}\right)$ & $\Delta \mathrm{T}(\mathrm{Tw}-\mathrm{Tg})\left({ }^{\circ} \mathrm{C}\right)$ & Qty (mL) & $\mathrm{Hs}(\mathrm{W} / \mathrm{m} 2)$ & $\mathrm{v}(\mathrm{m} / \mathrm{s})$ \\
\hline $10: 30$ & 33 & 30 & 3 & 0 & 630 & 1.7 \\
\hline $11: 30$ & 34 & 32 & 2 & 18 & 779 & 1.1 \\
\hline $12: 30$ & 38 & 34 & 4 & 65 & 966 & 0.6 \\
\hline $1: 30$ & 42 & 36 & 6 & 160 & 986 & 1.8 \\
\hline $2: 30$ & 45 & 38 & 7 & 320 & 956 & 0.2 \\
\hline $3: 30$ & 40 & 36 & 4 & 472 & 760 & 0.9 \\
\hline $4: 30$ & 38 & 33 & 5 & 513 & 455 & 0.1 \\
\hline $10: 30$ & & & & 350 & & \\
\hline Average & 38.29 & 34.14 & & & 760.29 & 0.92 \\
\hline Total Distillate & & & & 843 & & \\
\hline
\end{tabular}

Appendix C: Readings from Submerged Flat Absorber Still on 07/02/2014

\begin{tabular}{|c|c|c|c|c|c|c|}
\hline Time & $\mathrm{T}_{\mathrm{w}}\left({ }^{0} \mathrm{C}\right)$ & $\mathrm{T}_{\mathrm{g}}\left({ }^{0} \mathrm{C}\right)$ & $\Delta \mathrm{T}(\mathrm{Tw}-\mathrm{Tg})\left({ }^{\circ} \mathrm{C}\right)$ & Qty (mL) & $\mathrm{Hs}(\mathrm{W} / \mathrm{m} 2)$ & $\mathrm{v}(\mathrm{m} / \mathrm{s})$ \\
\hline $10: 30$ & 35 & 32 & 3 & 0 & 610 & 1.6 \\
\hline $11: 30$ & 37 & 34 & 3 & 10 & 750 & 1.2 \\
\hline $12: 30$ & 43 & 37 & 5 & 20 & 945 & 0.7 \\
\hline $1: 30$ & 46 & 40 & 6 & 58 & 975 & 1.6 \\
\hline $2: 30$ & 50 & 43 & 6 & 128 & 950 & 0.4 \\
\hline $3: 30$ & 48 & 39 & 5 & 210 & 755 & 0.6 \\
\hline $4: 30$ & 43 & 37 & 6 & 326 & 450 & 0.3 \\
\hline $10: 30$ & & & & 500 & & \\
\hline Average & 42.29 & 37.43 & & & 776.43 & 0.92 \\
\hline Total Distillate & & & & 826 & & \\
\hline
\end{tabular}

Appendix D: Readings from still without Submerged Absorber

\begin{tabular}{|c|c|c|c|c|c|c|}
\hline Time & $\mathrm{T}_{\mathrm{w}}\left({ }^{0} \mathrm{C}\right)$ & $\mathrm{T}_{\mathrm{g}}\left({ }^{0} \mathrm{C}\right)$ & $\Delta \mathrm{T}(\mathrm{Tw}-\mathrm{Tg})\left({ }^{\circ} \mathrm{C}\right)$ & Qty (mL) & $\mathrm{H}_{\mathrm{s}}\left(\mathrm{W} / \mathrm{m}^{2}\right)$ & $\mathrm{v}(\mathrm{m} / \mathrm{s})$ \\
\hline $10: 30$ & 35 & 32 & 3 & 0 & 610 & 1.6 \\
\hline $11: 30$ & 37 & 33 & 4 & 16 & 750 & 1.2 \\
\hline $12: 30$ & 43 & 37 & 6 & 46 & 945 & 0.7 \\
\hline $1: 30$ & 46 & 38 & 8 & 105 & 975 & 1.6 \\
\hline $2: 30$ & 50 & 41 & 9 & 188 & 950 & 0.4 \\
\hline $3: 30$ & 48 & 38 & 10 & 258 & 755 & 0.6 \\
\hline $4: 30$ & 43 & 35 & 8 & 381 & 450 & 0.3 \\
\hline $10: 30$ & & & & 440 & & \\
\hline Average & 42.86 & 37 & & & & \\
\hline Total Distillate & & & & 821 & 776.43 & 0.92 \\
\hline
\end{tabular}

Appendix E: Readings for Submerged Flat Absorber Still on 08/02/2014

\begin{tabular}{|c|c|c|c|c|c|c|}
\hline Time & $\mathrm{T}_{\mathrm{w}}\left({ }^{0} \mathrm{C}\right)$ & $\mathrm{T}_{\mathrm{g}}\left({ }^{0} \mathrm{C}\right)$ & $\Delta \mathrm{T}(\mathrm{Tw}-\mathrm{Tg})\left({ }^{\circ} \mathrm{C}\right)$ & Qty (mL) & $\mathrm{H}_{\mathrm{s}}\left(\mathrm{W} / \mathrm{m}^{2}\right)$ & $\mathrm{v}(\mathrm{m} / \mathrm{s})$ \\
\hline $10: 30$ & 33 & 30 & 3 & 0 & 640 & 1.5 \\
\hline $11: 30$ & 35 & 32 & 3 & 0 & 780 & 1.1 \\
\hline $12: 30$ & 37 & 33 & 4 & 12 & 970 & 1.5 \\
\hline $1: 30$ & 41 & 35 & 6 & 24 & 985 & 0.5 \\
\hline $2: 30$ & 46 & 39 & 7 & 72 & 961 & 0.9 \\
\hline $3: 30$ & 41 & 36 & 5 & 121 & 762 & 0.2 \\
\hline $4: 30$ & 37 & 31 & 6 & 194 & 440 & 0.7 \\
\hline $10: 30$ & & & & 550 & & \\
\hline Average & 38.57 & 33.71 & & & 791.14 & 0.92 \\
\hline Total Distillate & & & & 744 & & \\
\hline
\end{tabular}


Appendix F: Readings from still without Submerged Plate, 08/02/2014

\begin{tabular}{|c|c|c|c|c|c|c|}
\hline Time & $\mathrm{T}_{\mathrm{w}}\left({ }^{0} \mathrm{C}\right)$ & $\mathrm{T}_{\mathrm{g}}\left({ }^{0} \mathrm{C}\right)$ & $\Delta \mathrm{T}(\mathrm{Tw}-\mathrm{Tg})\left({ }^{\circ} \mathrm{C}\right)$ & Qty (mL) & $\mathrm{H}_{\mathrm{s}}\left(\mathrm{W} / \mathrm{m}^{2}\right)$ & $\mathrm{v}(\mathrm{m} / \mathrm{s})$ \\
\hline $10: 30$ & 36 & 32 & 4 & 0 & 640 & 1.5 \\
\hline $11: 30$ & 38 & 33 & 5 & 0 & 780 & 1.1 \\
\hline $12: 30$ & 43 & 35 & 8 & 9 & 970 & 1.5 \\
\hline $1: 30$ & 49 & 38 & 11 & 16 & 985 & 0.5 \\
\hline $2: 30$ & 51 & 41 & 10 & 58 & 961 & 0.9 \\
\hline $3: 30$ & 46 & 38 & 8 & 110 & 762 & 0.2 \\
\hline $4: 30$ & 40 & 34 & 6 & 185 & 440 & 0.7 \\
\hline $10: 30$ & & & & 510 & & \\
\hline Average & 43.29 & 35.86 & & & 791.14 & 0.92 \\
\hline Total Distillate & & & & 695 & & \\
\hline
\end{tabular}

\section{Design equations}

$A=\frac{m_{e} L}{H_{S} \eta}$.

$\mathrm{Y}=\mathrm{K}+\mathrm{B} \times \sin 11.333$

$\mathrm{A}=\mathrm{C} \mathrm{x}$

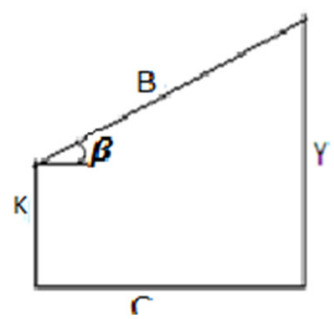

\section{Heat Balance on the Entire Still}

$$
Q_{e}=\alpha_{w} \tau_{g} H_{s}-\left(q_{r}+q_{c}+q_{b}\right)
$$

Radiative heat loss

$$
q_{r}=\frac{\sigma A_{e}\left[\left(T_{w}+273\right)^{4}-\left(T_{g}+273\right)^{4}\right]}{\frac{1}{\varepsilon_{r}}+\frac{A_{c}}{A_{g}}\left(\frac{1}{\varepsilon_{g}}-1\right)}
$$

Heat loss from base

$$
q_{b}=\frac{T_{w}-T_{a}}{\frac{X_{i n s}}{K_{i n s}}+\frac{1}{h_{c a}}+\frac{X_{c s}}{K_{c s}}}
$$

Efficiency and Capacity of the Still

Efficiency $\eta=\frac{Q_{e}}{H_{s}}$

Capacity $\mathrm{m}_{\mathrm{e}}=\frac{Q_{e}}{L}$

$$
q_{c}=0.884\left[T_{w}-T_{g}+\frac{\left(p_{w}-p_{g}\right)\left(T_{w}+273\right)}{268.9 \times 10^{3}-p_{w}}\right]^{\frac{1}{3}}\left(T_{w}-T_{g}\right)
$$

